\title{
Perbedaan Kadar Troponin T dan Troponin I Serum pada Berbagai Derajat Infeksi Virus Dengue Anak
}

Anthony Sudjadi, Dzulfikar DLH, Rahmat Budi Kuswiyanto

Bagian Ilmu Kesehatan Anak Fakultas Kedokteran Universitas Padjadjaran/RSUP Dr. Hasan Sadikin, Bandung

Latar belakang. Perbedaan kadar troponin T diketahui berhubungan dengan derajat infeksi virus dengue, tetapi belum diketahui pada troponin I.

Tujuan. Mengetahui perbedaan kadar troponin T dan I pada berbagai derajat infeksi virus dengue anak.

Metode. Penelitian observasional analitik, rancangan potong lintang pada anak kelompok demam dengue (DD), demam berdarah dengue tanpa syok (DBD), dan sindrom syok dengue (SSD) di RSUP Dr.Hasan Sadikin, RSUD: Majalaya, Cibabat, dan Kota Bandung. Troponin T dan I diperiksa saat awal perawatan dan fase pemulihan. Analisis: uji Kruskal Wallis +analisis post hoc, dan uji Wilcoxon. Hasil. Didapat 49 anak infeksi virus dengue. Hasil pemeriksaan kelompok DD, DBD, dan SSD (berturut-turut) adalah troponin $\mathrm{T}$ awal: 3,32, 3,0, 9,01 pg/mL, pemulihan (kurang jelas, lebih baik disebutkan rerata hari ke berapa sakit): 3,0, 3,0, 6,21 pg/mL, Troponin I awal: 2,10, 2,25, 14,20 ng/L, pemulihan: 2,10, 1,50, 14,35 ng/L. Perbedaan kadar troponin T awal: p=0,015, pemulihan: $\mathrm{p}=0,009$, troponin I awal: $\mathrm{p}=0,032$, pemulihan: $\mathrm{p}=0,062$. Perbedaan pemeriksaan awal dan fase pemulihan kelompok DD, DBD, dan SSD (berturut-turut): Troponin T: $\mathrm{p}=0,420,0,055,0,248$, Troponin I: $\mathrm{p}=0,202,0,077,0,285$.

Kesimpulan. Terdapat perbedaan kadar troponin T dan I pada berbagai derajat infeksi virus dengue anak, kecuali kadar troponin I fase pemulihan. Tidak terdapat perbedaan kadar troponin T dan I antara awal perawatan dan fase pemulihan. Sari Pediatri 2017;19(4):183-8

Kata kunci: troponin T, troponin I, dengue, anak

\section{Differences Serum Levels of Troponin $T$ and Troponin I at Various Degree in Children with Dengue Virus Infection}

Anthony Sudjadi, Dzulfikar DLH, Rahmat Budi Kuswiyanto

Background. Differences in troponin T levels are known have correlation with the degree of dengue virus infection, but the difference in troponin I levels are still unknown.

Objective. To know the differences of troponin $\mathrm{T}$ and $\mathrm{I}$ levels of $\mathrm{T}$ in various degrees of dengue virus infection in children

Methods. Analytical observational study, cross sectional design on children with dengue fever (DF group), dengue haemorhagic fever (DHF) without shock group, and dengue shock syndrome (DSS group) at Dr.Hasan Sadikin General Hospital, Majalaya Hospital, Cibabat Hospital and Bandung City Hospital. Troponin T and I were examined at the beginning of hospitalization and convalescent phase. Analysis using Kruskal Wallis Test with post hoc analysis and Wilcoxon test.

Results. 49 children with dengue virus infection were enrolled in the study. The examination results of DF, DHF, and DSS groups (respectively) were: Troponin T at admission: 3.32, 3.0, 9.01 pg/mL, convalescent: 3.0, 3.0, 6.21 pg/mL, Troponin I beginning: 2.10 , $2.25,14.20 \mathrm{ng} / \mathrm{L}$, convalescent: $2.10,1.50,14.35 \mathrm{ng} / \mathrm{L}$. Differences of baseline troponin T levels: $\mathrm{p}=0.015$, convalescent: $\mathrm{p}=0.009$, Troponin I at the beginning: $\mathrm{p}=0.032$, and at convalescent: $\mathrm{p}=0.062$. Differences in initial examination and convalescent phase of DD, DHF and SSD groups (respectively): Troponin T: $\mathrm{p}=0.420,0.055,0.248$, Troponin I: $\mathrm{p}=0.202,0.077,0.285$

Conclusions. There are a differences on troponin $\mathrm{T}$ and $\mathrm{I}$ levels between degrees of dengue virus infection in children, except in convaescent phase of troponin I, with the highest levels found in the case of DSS. There are no differences of troponin T and I levels between the beginning of hospitalization and convalescent phase. Sari Pediatri 2017;19(4):183-8

Keywords: troponin T, troponin I, dengue, children

Alamat korespondensi: Anthony Sudjadi, dr. Departemen Ilmu Kesehatan Anak Fakultas Kedokteran UNPAD Rumah Sakit Dr. Hasan Sadikin Bandung Jl. Pasteur no. 38 Bandung, Indonesia 40163. Email: anthonysudjadi@yahoo.com 
Anthony Sudjadi dkk: Perbedaan kadar troponin T dan I serum pada berbagai derajat infeksi virus dengue

$\mathrm{I}$ nfeksi virus dengue merupakan salah satu penyakit yang ditularkan melalui gigitan nyamuk dan memiliki angka morbiditas dan mortalitas yang tinggi ${ }^{1-3}$ Angka kejadian infeksi virus dengue mencapai 390 juta kasus setiap tahunnya di seluruh dunia dan didapatkan pada lebih dari 100 negara. ${ }^{1,4}$

Insidens infeksi virus dengue dilaporkan semakin meningkat, laporan mengenai terjadinya manifestasi klinis yang atipikal, termasuk keterlibatan/ gangguan jantung juga meningkat. Insidens keterlibatan jantung pada pasien infeksi virus dengue belum diketahui secara pasti. Berdasarkan penelitian-penelitian sebelumnya diperkirakan insidensi keterlibatan jantung pada infeksi virus dengue bervariasi 8-25\% kasus. ${ }^{5-8}$ Gangguan jantung terjadi akibat hipoperfusi, invasi langsung otot jantung, atau akibat respon imunologis. ${ }^{4,7,9}$ Gejala klinis keterlibatan jantung pada pasien infeksi virus dengue bervariasi luas, mulai dari tidak bergejala/silent disease hingga miokarditis berat yang menyebabkan kematian. ${ }^{4,10}$

Sebelumnya, telah dilakukan berbagai penelitian menggunakan biomarker jantung untuk mengetahui keterlibatan jantung pada infeksi virus dengue. , $, 8,11-13$ Biomarker jantung, seperti troponin T dan I, dapat mengindikasikan keterlibatan jantung pada pasien dengue. ${ }^{7,11}$ Namun, belum terdapat penelitian yang menilai biomarker terbaik dalam deteksi keterlibatan jantung pada pasien infeksi virus dengue. Kadar troponin I dan troponin T yang tinggi menunjukkan kemungkinan terjadi inflamasi atau iskemia pada miokardium. ${ }^{12,14}$

Penelitian yang dilakukan di Brazil pada populasi dewasa dengan infeksi virus dengue dilakukan pemeriksaan kadar troponin I dan pro- $B$ natriuretic peptide pada saat awal pasien dirawat inap dengan hasil didapatkan peningkatan kadar troponin I dan pro-B natriuretic peptide pada $15 \%$ pasien. ${ }^{12}$

Di Indonesia, penelitian mengenai hubungan kadar troponin $T$ pada pasien anak dengan infeksi virus dengue didapatkan hasil bahwa kadar troponin $\mathrm{T}$ ditemukan lebih tinggi pada kelompok pasien yang mengalami syok atau SSD dibanding dengan kelompok pasien tanpa syok. ${ }^{11}$

Tujuan penelitian ini adalah mengetahui perbedaan kadar troponin $\mathrm{T}$ dan I pada berbagai derajat infeksi virus dengue anak.

\section{Metode}

Penelitian observasional analitik dengan rancangan penelitian cross sectional pada pasien anak berusia 1 bulan hingga 13 tahun 11 bulan yang dirawat inap dengan diagnosis infeksi virus dengue di Rumah Sakit Umum Pendidikan (RSUP) Dr. Hasan Sadikin, Rumah Sakit Umum Daerah (RSUD) Majalaya, RSUD Cibabat, dan RSUD Kota Bandung selama bulan Maret-Juni 2017.

Kriteria inklusi penelitian adalah usia 1 bulan-13 tahun 11 bulan, pasien infeksi virus dengue, yang didiagnosis secara klinis (berdasar atas WHO tahun 2011) dan laboratoris (NS1 atau Antibodi antidengue (IgM) reaktif. Kriteria ekslusi adalah telah didiagnosis terdapat kelainan jantung sebelumnya, diketahui menderita penyakit infeksi virus atau bakteri lainnya, diketahui menderita penyakit otot seperti muscular dystrophy atau polimiositis, diketahui menderita penyakit ginjal, diketahui mengonsumsi obat-obatan kardiotoksik. Kriteria drop out adalah pulang paksa saat penelitian dilakukan, meninggal dunia, menolak dilakukan pemeriksaan kedua. Subjek penelitian kemudian dikelompokkan menjadi 3 kelompok, yaitu kelompok demam dengue (DD), kelompok demam berdarah dengue (DBD) tanpa syok, dan DBD dengan syok/sindrom syok dengue (SSD). Subjek penelitian minimal 46 subjek pasien infeksi virus dengue yang dilakukan dengan cara consecutive sampling.

Semua pasien yang memenuhi kriteria penelitian dicatat nama, usia, jenis kelamin, status gizi, tanda vital (suhu badan, nadi, tekanan darah, pernapasan), dilakukan pemeriksaan laboratorium berupa hemoglobin $(\mathrm{Hb})$, hematokrit (Ht), leukosit, trombosit, NS1 dan antibodi antidengue (SD Bioline Dengue Duo ${ }^{\circledR}$ ). Dilakukan juga pengukuran kadar high sensitive troponin $\mathrm{T}$ (Elecsys ${ }^{\circ}$ ) dan high sensitive troponin I (Vidas ${ }^{\circ}$ ) pada saat awal pasien masuk rumah sakit, baik pada fase demam ataupun fase kritis penyakit, dan pemeriksaan berikutnya dilakukan pada saat fase pemulihan penyakit dan dilakukan perbandingan.

Karakteristik subjek penelitian meliputi usia, jenis kelamin, kadar troponin T, dan troponin I pada anak yang terinfeksi virus dengue pada saat awal perawatan dan pada fase pemulihan. Kadar troponin $\mathrm{T}$ dan troponin I serum pada berbagai klasifikasi demam dengue disajikan dalam rata-rata, standar deviasi, median, nilai minimum dan maksimum untuk data numerik dan jumlah dan presentasi untuk data kategorik. 
Analisis bivariabel untuk menguji perbedaan kadar troponin $\mathrm{T}$ dan I pada berbagai derajat berat infeksi virus dengue digunakan uji Kruskal-Wallis. Selanjutnya dilakukan analisis post hoc, bermakna bila $\mathrm{p}<0,05$. Analisis bivariabel yang digunakan untuk menguji perbedaan kadar troponin $T$ dan troponin I pada anak yang terinfeksi virus dengue pada saat awal perawatan dan pada fase pemulihan menggunakan Wilcoxon Sign Rank Test, bermakna bila $\mathrm{p}<0,05$. Analisis data dilakukan menggunakan program statistical product and service solution (SPSS) for windows versi 21.0.

Penelitian mulai dilaksanakan setelah mendapat persetujuan Komite Etik Penelitian Kesehatan Fakultas Kedokteran Universitas Padjadjaran RSUP Dr. Hasan Sadikin Bandung.

\section{Hasil}

Terdapat 110 pasien anak yang didiagnosis klinis terinfeksi virus dengue, 49 anak yang memenuhi kriteria inklusi dan 3 orang mengundurkan diri. Selama 4 bulan penelitian didapatkan 22 pasien DD, 14 DBD tanpa syok, dan 10 SSD. Karakteristik subjek penelitian tertera pada Tabel 1.

Karakteristik subjek penelitian didapatkan usia pada kelompok DBD tanpa syok $(8,9 \pm 3,4$ tahun) lebih tinggi dibanding dengan kelompok DD $(5,6 \pm 3,3$ tahun) dan SSD (6,26 $\pm 3,7$ tahun). Pada hasil pemeriksaan laboratorium awal perawatan, kelompok SSD dan DBD tanpa syok memiliki kadar hemoglobin dan hematokrit yang lebih tinggi dibanding dengan kelompok DD. Kadar trombosit kelompok SSD didapatkan paling rendah dibanding dengan dua kelompok lainnya.

Pada penelitian ini pada saat awal pasien masuk rumah sakit didapatkan kadar hemoglobin dan hematokrit rata-rata kelompok SSD (hemoglobin $14,2 \pm 1,2$; hematokrit $42 \pm 3$ ) dan DBD tanpa syok (hemoglobin 14,2 $\pm 1,5$; hematokrit 42 \pm 5 ) lebih tinggi dibanding dengan kelompok DD (hemoglobin $11,8 \pm 1,2$; hematokrit $36 \pm 3$ ).

Tabel 1. Karakteristik subjek penelitian

\begin{tabular}{lccc}
\hline & \multicolumn{3}{c}{ Klasifikasi klinis infeksi dengue } \\
\cline { 2 - 4 } Variabel & $\mathrm{DD}$ & $\mathrm{DBD}$ & $\mathrm{DSS}$ \\
& $\mathrm{n}=22$ & $\mathrm{n}=14$ & $\mathrm{~N}=10$ \\
\hline Usia $($ tahun$)$ & $5,6 \pm 3,3$ & & $6,26 \pm 3,7$ \\
Jenis kelamin & & & \\
Laki-laki & $12(54,5)$ & $8(57,1)$ & $4(40)$ \\
Perempuan & $10(45,5)$ & $6(42,9)$ & $6(60)$ \\
Status gizi & & & \\
Baik & $17(77,3)$ & $6(42,9)$ & $5(50)$ \\
Kurang & $2(9,1)$ & $2(14,3)$ & $2(20)$ \\
Buruk & $1(4,5)$ & $2(14,3)$ & $1(10)$ \\
Lebih & $2(9,1)$ & $3(21,4)$ & $1(10)$ \\
Obesitas & $0(0,0)$ & $1(7,1)$ & $1(10)$ \\
Laboratorium & & & \\
Saat awal masuk RS & & & $14,2 \pm 1,2$ \\
Hemoglobin $(\mathrm{g} / \mathrm{dL})$ & $11,8 \pm 1,2$ & $14,2 \pm 1,5$ & $42 \pm 3$ \\
Hematokrit $(\%)$ & $36 \pm 3$ & $42 \pm 5$ & 7.281 \\
Leukosit $\left(/ \mathrm{mm}^{3}\right)$ & 4.350 & 4.857 & $(2.700-14.600)$ \\
& $(1.500-17.700)$ & $(2.560-10.080)$ & \\
Trombosit $\left(/ \mathrm{mm}^{3}\right)$ & $85.045 \pm 27.357$ & $78.571 \pm 36.807$ & $43.800 \pm 36.337$ \\
Saat fase pemulihan penyakit & & & $11,3 \pm 1,3$ \\
Hemoglobin $(\mathrm{g} / \mathrm{dL})$ & $11,3 \pm 1,2$ & $11,8 \pm 1,1$ & $34 \pm 4$ \\
Hematokrit $(\%)$ & $34 \pm 3$ & $34 \pm 4$ & 6.540 \\
Leukosit $\left(/ \mathrm{mm}^{3}\right)$ & 5.400 & 5.000 & $(4.400-9.900)$ \\
& $(2.020-19.900)$ & $(2.700-6.700)$ & $108.700 \pm 23.926$ \\
Trombosit $\left(/ \mathrm{mm}^{3}\right)$ & $113.091 \pm 35.988$ & $109.571 \pm 29.301$ & \\
\hline
\end{tabular}


Perbandingan kadar troponin $\mathrm{T}$ dan I antar berbagai derajat infeksi virus dengue anak tertera pada Tabel 2. Pada kelompok SSD, kadar troponin T saat awal perawatan dan fase penyembuhan lebih tinggi dibanding dengan kelompok DD dan DBD tanpa syok, dan bermakna secara statistik. Pada kelompok SSD, kadar troponin I saat awal perawatan lebih tinggi secara bermakna dibanding dengan kelompok DD dan DBD tanpa syok, tetapi tidak didapatkan perbedaan bermakna kadar troponin I pada fase penyembuhan penyakit.

Perbedaan kadar troponin T dan I antar kelompok derajat berat infeksi virus dengue dapat dilihat pada analisis post hoc. Kadar troponin T dan I didapatkan lebih tinggi secara bermakna pada kelompok SSD saat dibandingkan dengan dengan kelompok DD dan kelompok DBD tanpa syok, kecuali pada perbandingan antara kelompok SSD dan DD pada fase pemulihan penyakit. Tidak terdapat perbedaan bermakna kadar troponin $\mathrm{T}$ dan I antara kelompok DD dan DBD tanpa syok.
Perbedaan kadar troponin T dan I pada fase awal dengan fase pemulihan penyakit tertera pada Tabel 3. Pada penelitian ini tidak didapatkan perbedaan bermakna kadar troponin $\mathrm{T}$ dan I antara awal perawatan dan fase pemulihan penyakit.

\section{Pembahasan}

Karakteristik subjek penelitian didapatkan usia pada kelompok DBD tanpa syok $(8,9 \pm 3,4$ tahun) lebih tinggi dibanding dengan kelompok DD (5,6 $\pm 3,3$ tahun) dan SSD (6,26 $\pm 3,7$ tahun). Status gizi dibedakan menjadi baik, kurang, buruk, lebih, dan obesitas. Berdasarkan penelitian sebelumnya di Indonesia tidak terdapat perbedaan bermakna dalam status gizi pada pasien infeksi virus dengue anak yang diperiksakan kadar troponin T. ${ }^{11}$

Pada pemeriksaan laboratorium, kelompok SSD dan DBD tanpa syok didapatkan kadar hemoglobin

Tabel 2. Perbedaan kadar troponin T dan I antara pasien DD, DBD tanpa syok, dan SSD

\begin{tabular}{|c|c|c|c|c|}
\hline \multirow[b]{2}{*}{ Variabel } & \multicolumn{3}{|c|}{ Kelompok } & \multirow[b]{2}{*}{ Nilai p* } \\
\hline & $\begin{array}{c}\mathrm{DD} \\
(\mathrm{n}=22)\end{array}$ & $\begin{array}{c}\text { DBD tanpa syok } \\
(\mathrm{n}=14)\end{array}$ & $\begin{array}{c}\text { SSD } \\
(n=10)\end{array}$ & \\
\hline \multicolumn{5}{|l|}{$\begin{array}{l}\text { Troponin T } \\
(\mathrm{pg} / \mathrm{mL})\end{array}$} \\
\hline \multicolumn{5}{|l|}{ Awal perawatan } \\
\hline Median & 3,32 & 3,0 & 9,01 & 0,015 \\
\hline Rentang & $\begin{array}{c}3,00-60,63 \\
\text { (A) }\end{array}$ & $\begin{array}{c}3,00-27,16 \\
\text { (B) }\end{array}$ & $\begin{array}{c}3,00-84,74 \\
\text { (C) }\end{array}$ & \\
\hline \multicolumn{5}{|l|}{ Fase pemulihan } \\
\hline Median & 3,0 & 3,0 & 6,21 & 0,009 \\
\hline Rentang & $\begin{array}{c}3,00-77,65 \\
\text { (D) }\end{array}$ & $\begin{array}{l}3,0-18,58 \\
\text { (E) }\end{array}$ & $\begin{array}{c}3,00-43,40 \\
(\mathrm{~F})\end{array}$ & \\
\hline \multicolumn{5}{|l|}{$\begin{array}{l}\text { Troponin I } \\
\quad(n g / L)\end{array}$} \\
\hline \multicolumn{5}{|l|}{ Awal perawatan } \\
\hline Median & 2,10 & 2,25 & 14,20 & 0,032 \\
\hline Rentang & $\begin{array}{c}1,50-197,0 \\
(\mathrm{G})\end{array}$ & $\begin{array}{c}1,50-47,50 \\
(\mathrm{H})\end{array}$ & $\begin{array}{c}1,50-467,90 \\
\text { (I) }\end{array}$ & \\
\hline \multicolumn{5}{|l|}{ Fase pemulihan } \\
\hline Median & 2,10 & 1,50 & 14,35 & 0,062 \\
\hline Rentang & $\begin{array}{c}1,50-153,60 \\
(\mathrm{~J})\end{array}$ & $\begin{array}{c}1,50-21,40 \\
(\mathrm{~K})\end{array}$ & $\begin{array}{c}1,50-179,20 \\
(\mathrm{~L})\end{array}$ & \\
\hline $\begin{array}{l}\text { Keterangan: } \\
{ }^{*} \text { Analisis Uji Kru } \\
{ }^{* *} \text { Analisis post ho } \\
\text { C vs A (p=0,012) } \\
(\mathrm{p}=0,560) \text {, I vs } \mathrm{G}\end{array}$ & $\begin{array}{l}\text { ermakna } \mathrm{p}<0 \\
\text { Mann-Whitn } \\
=0,009), \mathrm{B} \text { vs } \\
\text { I vs } \mathrm{H}(\mathrm{p}=0,0\end{array}$ & $\begin{array}{l}\text { bermakna } p<0,05: \\
p=0,305), F \text { vs D (p } \\
\text { H vs I }(p=0,435)\end{array}$ & 035), $F$ vs $E$ ( & 03), E vs D \\
\hline
\end{tabular}


Anthony Sudjadi dkk: Perbedaan kadar troponin T dan I serum pada berbagai derajat infeksi virus dengue

Tabel 3. Perbedaan kadar troponin T dan I antara fase awal dan pemulihan pada kelompok DD, DBD tanpa syok, dan SSD

\begin{tabular}{lcccc}
\hline Kelompok & Waktu pemeriksaan & $\begin{array}{c}\text { Awal perawatan } \\
\text { Median (rentang) }\end{array}$ & $\begin{array}{c}\text { Fase pemulihan penyakit } \\
\text { Median (rentang) }\end{array}$ & $\mathrm{p}^{*}$ \\
\hline DD & troponin T & 3,32 & 3,00 & 0,420 \\
& troponin I & $(3,00-60,63)$ & $(3,00-77,65)$ & \\
& & 2,1 & 2,1 & 0,202 \\
DBD tanpa syok & troponin T & $3,5-197,0)$ & $(1,5-153,6)$ & \\
& & $(3,00-27,16)$ & $(3,00-18,58)$ & 0,055 \\
& troponin I & 2,25 & 1,5 & 0,077 \\
SSD & $(1,5-45,7)$ & $(1,5-21,4)$ & \\
& troponin T & 9,01 & 6,22 & 0,248 \\
& & $(3,00-84,74)$ & $(3,00-43,4)$ & \\
& troponin I & 14,2 & 14,4 & 0,285 \\
& & $(1,5-467,9)$ & $(1,5-179,2)$ & \\
\hline
\end{tabular}

Keterangan: *Analisis Uji Wilcoxon, bermakna $\mathrm{p}<0,05$

dan hematokrit yang lebih tinggi dibanding dengan kelompok DD. Kadar trombosit pada kelompok SSD didapatkan paling rendah dibanding dengan dua kelompok lainnya.

Saat awal pasien masuk ke rumah sakit didapatkan kadar hemoglobin dan hematokrit rata-rata kelompok SSD (hemoglobin 14,2 $\pm 1,2 \mathrm{~g} / \mathrm{dL}$, hematokrit $42 \pm 3 \%$ ) dan DBD tanpa syok (hemoglobin 14,2 $\pm 1,5 \mathrm{~g} /$ $\mathrm{dL}$, hematokrit $42 \pm 5 \%$ ) lebih tinggi dibanding dengan kelompok DD (hemoglobin 11,8 $\pm 1,2 \mathrm{~g} /$

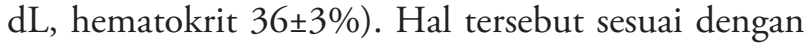
kriteria WHO yang menyatakan bahwa salah satu perbedaan antara pasien DD dan DBD adalah terdapatnya hemokonsentrasi pada pasien DBD, yaitu didapatkan peningkatan nilai hematokrit $\geq 20 \%$ daripada nilai dasar pasien. ${ }^{15}$

Didapatkan perbedaan yang bermakna kadar troponin T, baik pada awal perawatan maupun pada fase pemulihan antara kelompok DD, DBD tanpa syok, dan SSD. Pada pemeriksaan kadar troponin I didapatkan perbedaan bermakna kadar troponin I pada awal perawatan, tetapi tidak didapatkan perbedaan bermakna pada fase pemulihan penyakit. Kadar troponin T dan I tertinggi didapatkan pada kelompok SSD. Hal tersebut sesuai dengan penelitian di Indonesia yang menunjukkan kadar troponin $T$ yang lebih tinggi pada kasus SSD dibandingkan dengan dengan anak dalam kelompok demam berdarah tanpa syok. ${ }^{11}$

Kadar troponin didapatkan lebih tinggi pada kasus SSD karena didapatkan keadaan hipoperfusi yang dapat menyebabkan gangguan/kerusakan otot jantung yang dapat menyebabkan peningkatan kadar troponin serum. ${ }^{11}$ Pada SSD, terjadi pelepasan mendiator inflamasi yang lebih besar dibanding dengan infeksi virus dengue tanpa syok. Infeksi virus dengue dan hipoksia juga menginduksi pelepasan mediator inflamasi, seperti tumor necrosis factor alpha (TNF- $\alpha$ ) dan interleukin-1 (IL-1) dalam jumlah besar dapat menyebabkan penurunan tekanan darah dan hipoperfusi. ${ }^{7,10,16}$ Keadaan-keadaan tersebut dapat menyebabkan gangguan/cedera miokardium dan menyebabkan pelepasan troponin dari miosit ke dalam peredaran darah. ${ }^{17,18}$

Pada penelitian ini tidak terdapat perbedaan bermakna kadar troponin I pada fase pemulihan penyakit. Hal tersebut mungkin terjadi karena telah terjadi penurunan kadar troponin I pada fase pemulihan penyakit. Diperlukan penelitian lebih lanjut untuk membuktikan dan menjelaskan mengapa tidak terjadi perbedaan kadar troponin I pada fase pemulihan penyakit

Pada penelitian ini tidak didapatkan perbedaan bermakna kadar troponin $\mathrm{T}$ dan I antara awal perawatan dan fase pemulihan penyakit pada kelompok DD, DBD tanpa syok, dan SSD . Temuan ini mungkin disebabkan tidak dilakukannya pemeriksaan ulangan kadar troponin $\mathrm{T}$ dan I sebelum fase pemulihan penyakit. Abnormalitas kadar troponin dapat dideteksi dalam waktu 3-4 jam setelah onset gangguan miokardium dengan menggunakan pemeriksaan yang modern. ${ }^{17}$ 
Keterbatasan penelitian ini adalah tidak dilakukan pemeriksaan EKG atau ekokardiografi karena keterbatasan prasarana pada tempat penelitian dilakukan sehingga tidak dapat menentukan adanya gangguan jantung pada subjek penelitian.

Tidak ada informasi mengenai kondisi jantung subjek penelitian sebelum penelitian dilakukan karena pemeriksaan dilakukan saat awal pasien di rawat di rumah sakit

\section{Kesimpulan}

Terdapat perbedaan kadar troponin $\mathrm{T}$ dan troponin I antara kelompok DD, DBD tanpa syok, dan SSD, kecuali pada kadar troponin I fase pemulihan penyakit. Kadar troponin T dan I paling tinggi didapatkan pada kelompok DBD dengan syok (SSD). Tidak terdapat perbedaan kadar troponin $T$ dan I pada awal perawatan dengan fase pemulihan penyakit

\section{Daftar pustaka}

1. World Health Organization. Dengue and severe dengue. Fact sheets. Jenewa: WHO; 2013.

2. World Health Organization. Comprehensive guidelines for prevention and control of dengue and dengue hemorrhagic fever. Jenewa: WHO;2011.

3. Guzman MG, Halstead SB, Artsob H, Buchy P, Farrar J, Gubler DJ, dkk. Dengue: a continuing global threat. Nature Rev 2010;5:7-17.

4. Shivanthan MC, Navinan MR, Constantine GR, Rajapakse S. Cardiac involvement in dengue infection. J Infect Dev Ctries 2015;9:338-46.

5. Arora M, Patil RS. Cardiac manifestation in dengue fever. J Ass Phy Ind. 2016;64:40-4.

6. Méndez A, González G. Abnormal clinical manifestations of dengue hemorrhagic fever in children. Biomedica 2006;26:61-70.

7. Supachokchaiwattana P, La-orkhun V, Arj-ong S,
Sirichonkolthong B, Lertsapcharoen P, Khongphatthanayothin A. Reversible impairment of global cardiac function during toxic stage of dengue hemorrhagic fever and dengue shock syndrome. Thai Heart J 2007;20:180-7.

8. Kirawittaya T, Yoon IK, Wichit S, Green S, Ennis FA, Gibbons RV, dkk. Evaluation of cardiac involvement in children with dengue by serial echocardiographic studies. PLOS Neg Trop Dis. 2015;9:1-17.

9. Karyanti MR, Uiterwaal CSPM, Kusriastuti R, Hadinegoro SR, Rovers MM, Heesterbeek H, dkk. The changing incidence of dengue haemorrhagic fever in Indonesia: a 45-year registrybased analysis. BMC Inf Dis 2014;14:1-7.

10. Yacoub S, Werhelm H, Simmons C, Screaton G, Wills B. Cardiovascular manifestations of the emerging dengue pandemic. Nat Rev Cardiol 2014;11:335-45.

11. Iskandar B, Juherinah, Daud D, Febriani ADB. The levels of troponin $\mathrm{T}$ in patients with dengue hemorrhagic fever. AJCEM 2015;3:149-53.

12. Miranda $\mathrm{CH}$, Borges MdC, Matsuno AK, Vilar FC, Gali LsG, Volpe GJ, dkk. Evaluation of cardiac involvement during dengue viral infection. Clin Inf Dis 2013;1:1-8.

13. Kularatne $S$, Pathirage M, Kumarasiri P, Gunasena $S$, Mahindawanse S. Cardiac complications of a dengue fever outbreak in Sri Lanka, 2005. Trans R Soc Trop Med Hyg 2007;101:804-8.

14. Parmacek M, Solaro RJ. Biology of the troponin complex in cardiac myocytes. Elsevier. 2004;47:159-76.

15. World Health Organization. Dengue: guideines for diagnosis, treatment, prevention and control. New Edition. Jenewa: WHO; 2009.

16. Wichmann D, Kularatne S, Ehrhardt S, Wijesinghe S, Bratting N, Abel W, dkk. Cardiac involvement In dengue virus infections during the 2004/2005 dengue fever season in Sri Langka. Southeast Asian J Trop Med Public Health 2009;40:727-30.

17. Korff S, Katus HA, Giannitsis E. Differential diagnosis of elevated troponins. Heart 2006;92:987-93.

18. Finsterer J, Stöllberger C, Krugluger W. The release of TNF- $\alpha$ in such a large amount could cause decrease in blood pressure or shock and hypoperfusion. Neth J Med 2007;65:289-94. 